\title{
ANATOMICAL STUDY OF NUTRIENT FORAMINA IN DRIED HUMAN UPPER LIMB BONES AND THEIR CLINICAL SIGNIFICANCE
}

\author{
Udayasree L1, Ravindranath G2, Maheswari K. B33, Siva Prasad G. V4
}

${ }^{1}$ Associate Professor, Department of Anatomy, NRIIMS, Sangivalasa, Visakhapatnam.

2Professor and HOD, Department of Anatomy, NRIIMS, Sangivalasa, Visakhapatnam.

${ }^{3}$ Tutor, Department of Anatomy, NRIIMS, Sangivalasa, Visakhapatnam.

${ }^{4}$ Associate Professor, Department of Anatomy, NRIIMS, Sangivalasa, Visakhapatnam.

\section{ABSTRACT}

\section{BACKGROUND}

Nutrient artery is the major source of blood supply to the long bone, which enters through the nutrient foramen. Lack of adequate vascular supply can significantly delay or prevent fracture healing.

The aim of this study is to study the number, location and direction of nutrient foramina of human upper limb long bones (Humerus, Radius and Ulna).

\section{MATERIALS AND METHODS}

The study was conducted on 116 upper limb long bones, which included 39 humeri, 39 radii and 38 ulnae.

\section{RESULTS}

The variations found in number and location of nutrient foramina were observed. In humerus single, double and triple nutrient foramina were seen. No nutrient foramen in one radius and double nutrient foramina were observed in case of ulnae.

\section{CONCLUSION}

An understanding of the location and the number of the nutrient foramina in long bones is important in orthopaedic surgical procedures such as joint replacement, fracture repair and bone grafts.

\section{KEYWORDS}

Nutrient Foramen, Nutrient Artery, Upper Limb Long Bones (Humerus, Radius and Ulna) and Foraminal Index.

HOW TO CITE THIS ARTICLE: Udayasree L, Ravindranath G, Maheswari KB, et al. Anatomical study of nutrient foramina in dried human upper limb bones and their clinical significance. J. Evolution Med. Dent. Sci. 2017;6(2):110-113, DOI: $10.14260 /$ Jemds/2017/28

\section{BACKGROUND}

An opening into the bone shaft for the passage of blood vessels to the medullary cavity of a bone for its nourishment and growth is called as nutrient foramen. Nutrient artery is important during its active growth period in embryonic and foetal life. All long bones have one or more nutrient arteries, which enter through a nutrient foramen without branching in the foramen and that are accompanied by several thin walled veins and a myelinated nerve. ${ }^{1}$ The nutrient artery and its ascending and descending medullary branches form the important source of blood supply to the bone marrow and inner $2 / 3^{\text {rds }}$ of the compact part of the diaphysis. ${ }^{2}$ Usually nutrient arteries move away from the growing ends of the long bones. ${ }^{3}$ Detailed study of blood vessels and intact vascularity is required for fracture healing, bone grafts and other Orthopaedic procedures. ${ }^{4}$ During pregnancy intake of some of the drugs like thalidomide interferes with vascularisation and leads to death of mesenchymal cells in

Financial or Other, Competing Interest: None.

Submission 30-11-2016, Peer Review 21-12-2016,

Acceptance 30-12-2016, Published 05-01-2017.

Corresponding Author:

Dr. Udayasree $L$,

D. No. 53-38-7/3/11,

SF1-Siva Karthik Residency,

Behind Maddilapalem Sivalayam,

KRM Colony, Maddilapalem,

Visakhapatnam-530013.

E-mail: thesensitiveramesh@gmail.com

DOI: $10.14260 /$ jemds $/ 2017 / 28$

\section{(c) $(1)$}

the early limb bud causing phocomelia. ${ }^{5}$ The detailed study of number, location and direction of nutrient foramina in upper limb long bones is useful for the Orthopaedic surgeons to do surgical procedures on the bones.

\section{MATERIALS AND METHODS}

For this study, total 116 long bones of upper limb (Humeri39, Radii-39 and Ulnae-38) were taken from the Department of Anatomy, NRI Institute of Medical Sciences, Sangivalasa, Visakhapatnam. Each bone was examined with the help of hand lens and hypodermic needle to identify the position, number and the direction of nutrient foramen. The nutrient foramen was identified by the presence of a well-marked groove and raised edge at the commencement of the canal. The exact position of the nutrient foramen was made out whether it was present on the upper, middle or lower onethird of the body of the long bone. The total length of long bones and distance of nutrient foramen from the upper end were also measured by vernier calipers and osteometric board. The position of nutrient foramen was determined by calculating the Foraminal Index (FI) using the formula: $\mathrm{FI}=$ DNF/TL*100. [DNF = Distance of Nutrient Foramen from the upper end of the bone, TL = Total Length of the bone]. The position of the foramina was divided into 3 types according to FI. ${ }^{6}$

Type 1 - FI below 33.33, the foramen was in the proximal $1 / 3^{\text {rd }}$ of the bone.

Type 2 - FI ranges between 33.33 and 66.66, the foramen was in the middle $1 / 3^{\text {rd }}$ of the bone. 
Type 3 - FI more than 66.66, the foramen was in the lower $1 / 3^{\text {rd }}$ of the bone.

Broken ends of long bones were excluded due to lack of total length of the bone for measurement. Age and sex of the bones were not considered in the present study.

\section{RESULTS}

\section{Humerus}

Out of 39 bones, 30 (77\%) bones had single nutrient foramen, two foramina were present in $7(18 \%)$ bones and three foramina were found in $2(5 \%)$ bones. The mean foraminal index was 54.98. In 38 bones, foramen was present in middle $1 / 3^{\text {rd }}$ and 1 bone had foramen in the lower $1 / 3^{\text {rd }}$ of shaft. It was present on anteromedial surface in 34 bones, anterolateral surface in 3 bones and was present on posterior surface in 2 bones. All foramina were directed downwards towards elbow (Figure 1, 2).

\begin{tabular}{|c|c|c|c|c|c|c|c|c|c|}
\hline \multirow{2}{*}{$\begin{array}{c}\text { No. of } \\
\text { Bones }\end{array}$} & $\begin{array}{c}\text { One } \\
\text { Nutrient } \\
\text { Foramen }\end{array}$ & $\begin{array}{c}\text { Two } \\
\text { Nutrient } \\
\text { Foramina }\end{array}$ & $\begin{array}{c}\text { Three } \\
\text { Nutrient } \\
\text { Foramina }\end{array}$ & \multicolumn{2}{|c|}{ None } \\
\cline { 2 - 10 } & No. & $\%$ & No. & $\%$ & No. & $\%$ & No. & $\%$ \\
\hline Humeri & 39 & 30 & 77 & 7 & 18 & 2 & 5 & -- & -- \\
\hline Radii & 39 & 37 & 95 & -- & -- & -- & -- & 2 & 5 \\
\hline Ulnae & 38 & 37 & 97 & 1 & 3 & -- & -- & -- & -- \\
\hline \multicolumn{8}{|c|}{} \\
\hline \multicolumn{8}{|c|}{\begin{tabular}{c} 
Table I. Showing the Number and \\
\hline
\end{tabular}}
\end{tabular}

\section{Radii}

Out of 39 radii, (37) $95 \%$ of bones had single nutrient foramen, (2) $5 \%$ of bones had no foramen at all. Its foraminal index was 34.14. All foramina were present on anterior surface of radius; 33 bones had foramen in the middle $1 / 3^{\text {rd }}$ and 6 had in the upper $1 / 3^{\text {rd }}$ of the shaft (Figure 3 ).

\begin{tabular}{|c|c|c|c|}
\hline $\begin{array}{c}\text { Name of } \\
\text { the Bone }\end{array}$ & $\begin{array}{c}\text { Mean of Total } \\
\text { Length } \\
\text { cm }\end{array}$ & $\begin{array}{c}\text { Mean Distance of } \\
\text { NF from Upper } \\
\text { End of the Bone cm }\end{array}$ & $\begin{array}{c}\text { Foraminal } \\
\text { Index (FI) }\end{array}$ \\
\hline Humeri & 30.20 & 16.73 & 54.98 \\
\hline Radii & 23.84 & 8.13 & 34.14 \\
\hline Ulnae & 25.85 & 9.01 & 34.91 \\
\hline \multicolumn{3}{|c|}{ Table II. Showing the Mean } \\
calculation of FI (Foraminal Index) \\
\hline
\end{tabular}

\section{Ulnae}

Out of 38 bones, 37 (97\%) had single nutrient foramen and in one $(3 \%)$ bone two nutrient foramina were present. In 33 bones, nutrient foramen was present in middle $1 / 3^{\text {rd }}$ and in 5 it was in upper $1 / 3^{\text {rd }}$. In 37 bones, foramen was found on anterior surface and in one it was present on interosseous border. The mean foraminal index was 34.91. In ulnae and radii, all the nutrient foramina were directed proximally (Figure 4).

\begin{tabular}{|l|c|c|c|c|c|c|}
\hline \multicolumn{2}{|c|}{$\begin{array}{c}\text { No. of } \\
\text { Bones }\end{array}$} & $\begin{array}{c}\text { Upper } \\
\text { 1/3rd } \\
\text { (Type 1) }\end{array}$ & $\begin{array}{c}\text { Middle } \\
\text { 1/3rd } \\
\text { (Type 2) }\end{array}$ & $\begin{array}{c}\text { Lower } \\
\text { 1/3rd } \\
\text { (Type 3) }\end{array}$ & Expected & Variant \\
\hline Humeri & 39 & -- & 38 & 1 & $\begin{array}{c}\text { Antero- } \\
\text { Medial- } \\
34\end{array}$ & $\begin{array}{c}\text { Antero- } \\
\text { Lateral-3, } \\
\text { Posterior-2 }\end{array}$ \\
\hline Radii & 39 & 6 & 33 & -- & $\begin{array}{c}\text { Antero- } \\
\text { Surface- } \\
37\end{array}$ & Foramen-2 \\
\hline Ulnae & 38 & 5 & 33 & -- & $\begin{array}{c}\text { Anterior } \\
\text { Surface- } \\
37\end{array}$ & $\begin{array}{c}\text { Interosseous } \\
\text { Border-1 }\end{array}$ \\
\hline \multicolumn{2}{|c|}{ Table III. Showing the Position of the Nutrient Foramina } \\
\hline
\end{tabular}

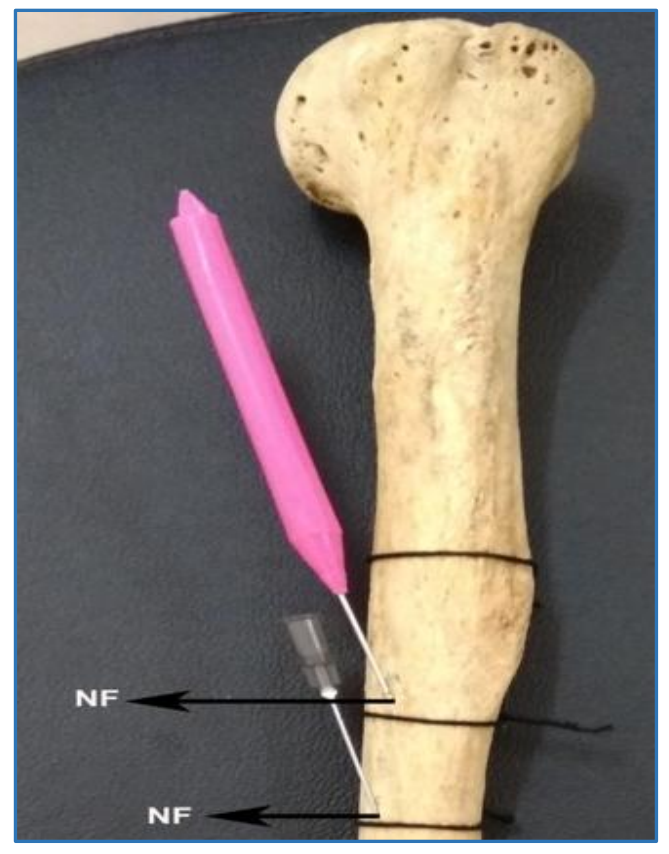

Figure 1. Shaft of Humerus showing Three Nutrient Foramina (NF), 2 with Needles on Anteromedial Surface and One on Posterior Surface. All are Located in the Middle 1/3rd (Type 2) of Shaft and are Directed Downward

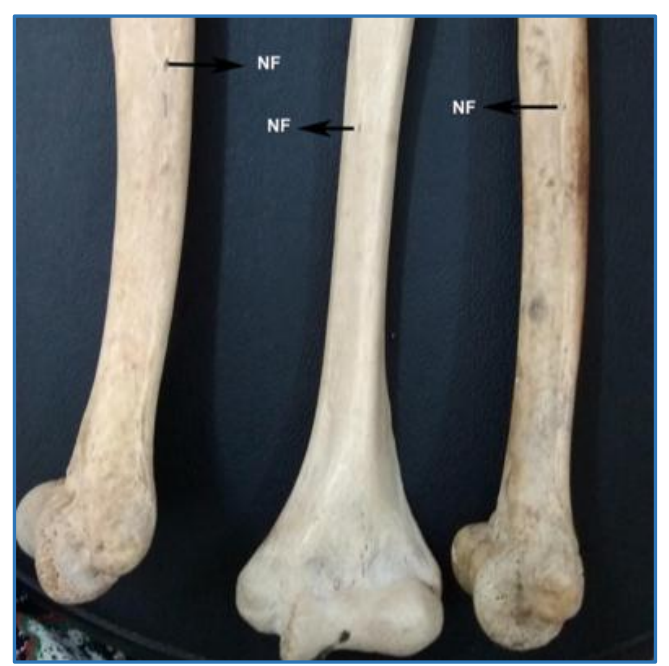

Figure 2. Shaft of Humeri showing Nutrient Foramina (NF) on Anteromedial Surface, Located in the Middle 1/3rd (Type 2) of Shaft and are Directed Downward 


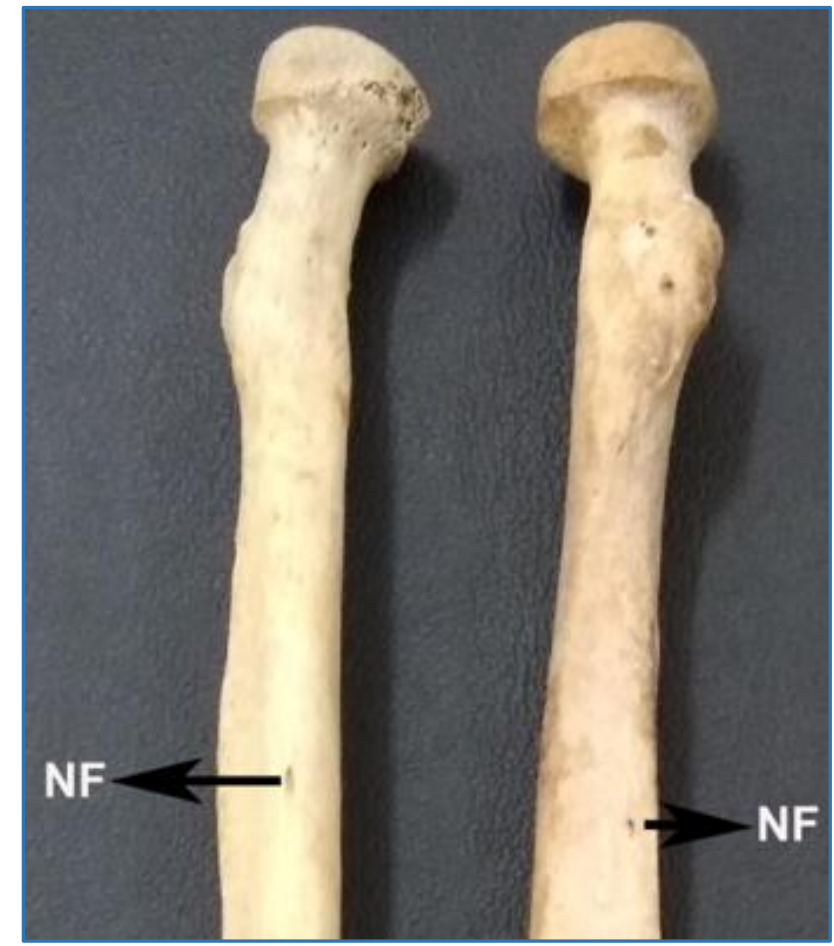

Figure 3. Shaft of Radii showing Nutrient Foramina (NF) on Anterior Surface, are Located in the Middle 1/3rd (Type 2) of Shaft and are Directed Upward

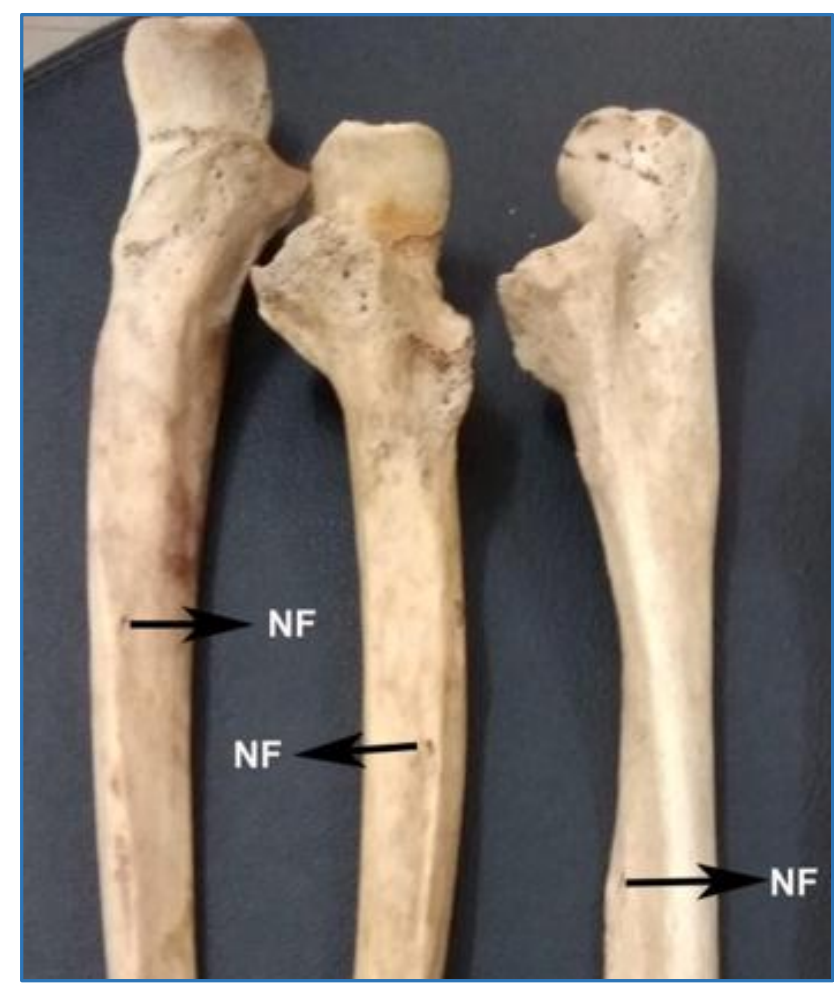

Figure 4. Shaft of Ulnae showing Nutrient Foramina (NF) on Anterior Surface, are Located in the Middle 1/3rd (Type 2) of Shaft and are Directed Upward

\section{DISCUSSION}

\section{Embryogenesis}

The osteogenic layer of periosteum forms the periosteal bud which contains osteoclasts, osteoblasts and blood vessels. The bud excavates passages through the newly formed bones and passes into the calcified matrix as the primary centre of ossification. The perforation of the bud persists as the nutrient canal. ${ }^{7}$

In the present study out of 39 humeri $77 \%$ (30) had one nutrient foramen, $18 \%$ (7) had two nutrient foramina and three foramina were found in $2(5 \%)$ of bones (Figure 1 and Table 1). According to Asharani SK and Ajay Ningaiah,8 87\% of bone had one nutrient foramen, $11 \%$ had two foramina. Anusha P and Naidu $\mathrm{MP}^{9}$ reported that 2 bones (4\%) had no foramen and Sabah $Y$ et al ${ }^{10}$ observed that $2 \%$ of bones had three foramina.

In the present study out of 39 humeri, $87.2 \%$ of bones had nutrient foramen on anteromedial surface (Figure 1 and 2), $7.7 \%$ on anterolateral surface and in $5.1 \%$ of bones it is present on posterior surface. According to Abdul SK et al ${ }^{11}$ $96 \%$ foramina were located on anteromedial surface, $2.66 \%$ on the posterior surface and $1.33 \%$ on anterolateral surface. In $97.4 \%$ of humeri, all the foramina were present in the middle $1 / 3^{\text {rd }}$ and $2.6 \%$ foramina were present in lower $1 / 3^{\text {rd }}$ of humerus. According to Sabah Y et al, ${ }^{10} 89 \%$ had foramina in middle $1 / 3^{\text {rd }}$ and $11 \%$ had foramina in the lower $1 / 3^{\text {rd }}$ of humerus. All are directed towards elbow joint. The mean blood supply to the shaft of the humerus is through a restricted area and one must be careful to guard against injuring this vessel in operations on the shaft of humerus. ${ }^{12} \mathrm{~A}$ posterolateral approach is therefore recommended to minimise damage to the blood supply of the humerus and limiting the chances of delayed or non-union in fracture shaft of the humerus.

In the present study out of 39 radii, $95 \%$ had single nutrient foramen and 5\% had no foramen (Figure 3). Mani $\mathrm{A}^{13}$ observed that single nutrient foramen was present in 98.17\% and Anusha P and Naidu MP9 observed that $92 \%$ of radii had single nutrient foramen, $6 \%$ had two foramina and $1 \%$ had no foramen. In the present study, 33 bones had foramen in middle $1 / 3^{\text {rd }}$ and are present on anterior surface; 6 bones had foramen in upper $1 / 3^{\text {rd }}$ of shaft of radius. All are directed towards elbow joint.

In the present study out of 38 ulnae, $97 \%$ had single and $3 \%$ had two nutrient foramina. In 33 bones, it was present in middle $1 / 3^{\text {rd }}$ and in 5 bones it was present in upper $1 / 3^{\text {rd }}$ of ulna (Figure 4); 37 bones had foramen on anterior surface and one had foramen on interosseous border. According to the study done by Prasad Rao KRS and Janaki V14 on 98 ulnae, 66 bones had single foramen, 20 had double, triple in 4 bones, four foramina in 6 bones and five foramina in 2 bones; 74 foramina were present in middle $1 / 3^{\text {rd }}, 50$ in upper $1 / 3^{\text {rd }}$ and 28 are found in lower $1 / 3^{\text {rd }}$ of ulnae. They found most of the foramina on anterior surface.

Knowledge of the number and position of the nutrient foramen in long bones was important in orthopaedic surgical procedures such as joint replacement therapy, fracture repair, bone grafting and vascularised bone microsurgery. The foramen might be a potential area of weakness in some patients and when under stress because of increased physical activity or decreased quality of the bone, the foramen might allow the development of a fracture. Position of the fracture relative to the nutrient foramen of the long bone and the pattern of oedema were the key features in the diagnosis of this type of fracture. 15 


\section{CONCLUSION}

In the present study of upper limb long bones, mostly single nutrient foramen was present and in few two or three were present on humeri and ulnae. Almost all foramina were present in middle $1 / 3^{\text {rd }}$ and on anteromedial and anterior surfaces. The knowledge of this position and number of nutrient foramina in long bones was useful for orthopaedic surgeons to treat fractures and other interventional surgeries and non-union of fracture ends.

\section{REFERENCES}

[1] Turek SL. Blood supply of long bones. Chapter 6. In: Orthopaedics: principles and their application. $4^{\text {th }}$ edn. Vol. 1. New Delhi: Wolters Kluwer/Lippincott Williams \& Wilkins 2011:180-6.

[2] Datta AK. Ossification. Chapter 2. In: Essentials of human osteology. 2nd edn. Kolkata: Current Books International 2005:22-5.

[3] Malukar 0, Joshi H. Diaphysial nutrient foramina in long bones and miniature long bones. NJIRM 2011;2(2):23-6.

[4] Kizilkanat E, Boyan N, Ozsahin ET, et al. Location, number and clinical significance of nutrient foramina in human long bones. Ann Anat 2007;189(1):87-95.

[5] Johnson D, Collins P. Pectoral girdle and upperlimb. Chapter 52. In: Standring S, ed. Gray's anatomy: the anatomical basis of clinical practice. $40^{\text {th }}$ edn. Churchill Livingstone 2010:905-6.

[6] Shulman SS. Observations of the nutrient foramina of the human radius and ulna. Anat Rec 1959;134:68597.
[7] Datta AK. The sclerous tissue. Chapter 6. In: Principles of general anatomy. $6^{\text {th }}$ edn. Kolkata: KP Basu Publishing Co 2005:68-73.

[8] Asharani SK, Ningaiah A. A study on the nutrient foramen of humerus. Int J Anat Res 2016;4(3):2706-9.

[9] Anusha P, Naidu MP. A study on the nutrient foramina of long bones. Jour of Med Sc \& Tech 2013;2(3):150-7.

[10] Yaseen S, Nitya W, Ravinder M. Morphological and topographical study of nutrient foramina in adult humeri. International journal of innovative research \& development, 2014;3(4):7-10.

[11] Abdul SK, Shah Z, Inayat Q. Anatomical variations in diaphyseal nutrient foramina of humerus in cadavers from Khyber Pakhtunkhwa, Pakistan. KMUJ 2014;6(1):18-21.

[12] Kennedy JC, Wyatt JK. An evaluation of the management of fracture through the middle third of humerus. Can J Surg 1957;1(1):26-33.

[13] Arora M. Morphometric study of nutrient foramina of human radii and their surgical importance. Indian Journal of Basic \& Applied Medical Research 2011;1(1):86-91.

[14] Prasad Rao KRS, Janaki V. Morphometric study of Nutrient foramina of human Radii-in Telangana region. Indian Journal of Applied Research 2016;6(9):92-94.

[15] Craig JG, Widman D, Van Holsbeeck M. Longitudinal stress fracture: patterne of edema and the importance of the nutrient foramen. Skeletal Radiology 2003;32(1):22-7. 